5. Машковська Л. В. Поняття, види та правова природа товаророзпорядчих документів як об'єктів ринку цінних паперів. Науковий вісник Ужсгородського національного університету. Серія Право. 2014. Випуск 24. Том 2. С. 140-144.

6. Струць М. Аграрні розписки: реалії і перспективи. Юрист \&Закон: электронное издание. 2016. № 20. URL: http://imgpartners.com.ua/company/ publications/agrarni-rozpiskirealii-iperspektivi-643-643/.

7. Фінансова аграрна розписка: Інструкція по використанню. URL: http://minagro.gov. ua/system/files

8. Товарна аграрна розписка. Зразок, розроблений експертами Проекту IFC «Аграрні розписки в Україні». URL: http://www.apk.sm.gov.ua/images/docs/agrarny_rozpusky/Commodity_ CR_Template_Final.pdf.

9. Туєва О. М. Аграрні розписки як інструмент кредитування аграрних товаровиробників. Сучасні тендениії та перспективи розвитку аграрного, земельного та екологічного права : матеріали Всеукр. наук.-практ. конф. (22-23 трав. 2015 р.), присвяч. 90-річчю від народж. акад. В. 3. Янчука. Київ, 2015. С. 187-189.

10. Самойлюк I. Застава майбутнього врожаю. Юридичний радник. 2012. № 6 (66). URL: http://yurradnik.com.ua/stati/

УДК 346.93

Р. В. Міліціанов

суддя господарського суду

Вінницької області,

канд. юрид. наук

\title{
ОПЛАТА КРЕДИТОРАМИ ОСНОВНОЇ ГРОШОВОЇ ВИНАГОРОДИ АРБІТРАЖНОГО КЕРУЮЧОГО
}

Ключові слова: банкрутство, арбітражний керуючий, ліквідатор, грошова винагорода арбітражного керуючого.

Незважаючи на відсутність у новій редакції Закону України «Про відновлення платоспроможності боржника або визнання його банкрутом» (далі Закон про банкрутство) [1] обов'язку суду затверджувати розмір основної грошової винагороди арбітражного керуючого, суд перевіряє правильність нарахування такої винагороди з метою забезпечення законності провадження у справі про банкрутство.

Вірне визначення розміру грошової винагороди арбітражного керуючого впливає на дотримання інтересів кредиторів при розподілі грошових коштів у справі про банкрутство. Належний розмір оплати праці арбітражного керуючого у справі про банкрутство також має забезпечити ефективне виконання покладених на нього обов'язків, що надасть можливість відновити платоспроможність боржника або максимально зменшити майнові втрати кредиторів у випадку ліквідації підприємства.

У юридичній науці зазначеним аспектам раніше приділяли увагу С. В. Міньковський, П. Д. Пригуза, В. Я. Погребняк, В. В. Джунь, Б. М. Поляков 
та інші вчені. Зокрема, С. В. Міньковський запропонував диференціювати розмір грошової винагороди в залежності від обсягу, складності роботи арбітражного керуючого, виду суб'єктів підприємницької діяльності [2]. П. Д. Пригуза наголошує на необхідності вдосконалення норм Закону про банкрутство щодо принципів та критеріїв визначення розміру винагороди арбітражного керуючого i конкретних джерел їх виплати при відсутності (недостатності) коштів боржника на їх покриття [3]. В. Я. Погребняк зазначає, що відсутності майнових активів у боржника, виплата грошової винагороди та відшкодування витрат арбітражному керуючому здійснюється за рахунок коштів кредиторів [4]. Однак, недослідженим залишається питання виплати винагороди ліквідатору у випадку реалізації виключно заставного майна, оскільки у такому випадку усі отримані грошові кошти мають перераховуватись заставному кредитору.

3 урахуванням наведеного вище, дослідження цієї теми є актуальним як теоретичної, так і практичної точки зору.

Метою цієї статті є обтрунтування пропозицій щзодо обчислення грошової винагороди арбітражного керуючого, а також ї̈ відшкодування кредиторами у разі виконання арбітражним керуючим повноважень ліквідатора підприємства.

Грошова винагорода арбітражного керуючого за виконання повноважень розпорядника майна визначається в розмірі двох мінімальних заробітних плат за кожний місяць виконання ним повноважень або в розмірі середньомісячної заробітної плати керівника боржника (ч. 2 ст. 115 Закону про банкрутство).

Єдиним нормативним актом, який визначає порядок обчислення середньої заробітної плати є постанова Кабінету Міністрів України (далі - КМУ) від 8 лютого 1995 р. № 100 [5]. Її застосування до визначення розміру винагороди арбітражного керуючого обумовлено також його правовим статусом як службової особи підприємства-боржника.

Тобто, при обчисленні розміру винагороди арбітражного керуючого слід брати до уваги розмір фактично виплаченої заробітної плати, а не нарахованої до виплати.

Відповідно до п. 37 Інформаційного листа Вищого господарського суду України (далі - ВГСУ) «Про Закон України «Про відновлення платоспроможності боржника або визнання його банкрутом» (у редакції Закону України від 22.12.2011 № 4212-VI)» у разі неотримання керівником боржника заробітної плати за останні дванадцять місяців його роботи, основна грошова винагорода арбітражного керуючого за виконання повноважень керуючого санацією, ліквідатора визначається в розмірі чотирьох мінімальних заробітних плат [6].

3 урахуванням норм постанови КМУ № 100 [5], які визначають спосіб обчислення середньої заробітної плати шляхом складання доходу працівника за 12 місяців роботи та поділу отриманої суми на кількість місяців, можна запропонувати положення п. 37 Інформаційного листа ВГСУ [6] застосовувати у випадку неотримання керівником боржника заробітної плати протягом останніх 12 місяців взагалі. Адже, у такому випадку буде відсутньою база розрахунку середньої заробітної плати. Тому виплата заробітку хоча б у одному місяці 
протягом останніх дванадцяти надає можливість здійснити розрахунок за правилами постанови КМУ № 100.

Якщо середньомісячна заробітна плата є меншою ніж мінімальна заробітна плата, то згідно з ч. 2 ст. 4 Закону про банкрутство арбітражний керуючий прирівнюється до службової особи підприємства, тобто застосуванню підлягають стандарти трудового законодавства.

Отже, заробітна плата арбітражного керуючого не може бути нижче мінімальної.

Водночас, оскільки не допускається звуження соціальних стандартів в силу ст. 22 Конституції України [7], то мінімальний розмір винагороди ліквідатора, керуючого санацією не може бути нижчим за дві мінімальні заробітні плати.

Таким чином, визначений ч. 2 ст. 115 Закону про банкрутство розмір основної грошової винагороди $\epsilon$ мінімально соціальною гарантією оплати праці арбітражного керуючого за виконання повноважень у справі про банкрутство.

Спірним є питання щодо визначення джерела оплати коштів у справі про банкрутство на стадії ліквідаційної процедури, зокрема, у випадку відсутності майна боржника або реалізації виключно заставного майна та перерахування отриманих коштів заставному кредитору.

На підставі ч. 5 ст. 115 Закону сплата грошової винагороди та відшкодування витрат арбітражного керуючого у зв'язку з виконанням ним повноважень у справі про банкрутство здійснюються за рахунок: наявних у боржника коштів, одержаних у результаті господарської діяльності боржника, або коштів, одержаних від продажу майна (майнових прав) боржника. Кредитори можуть створювати фонд для авансування грошової винагороди та відшкодування витрат арбітражного керуючого. Формування фонду та порядок використання його коштів визначаються рішенням комітету кредиторів та затверджуються ухвалою господарського суду. Арбітражний керуючий (розпорядник майна, керуючий санацією, ліквідатор) виконує повноваження за грошову винагороду (ч. 1 ст. 115 Закону про банкрутство).

Таким чином, нормами Закону не передбачено можливості безоплатного виконання повноважень арбітражного керуючого.

Критерієм нарахування та виплати заробітної плати $є$ саме виконання обов'язків розпорядника, а не факт перебування на посаді. Доказами виконання обов'язків є вчинення дій, передбачених ст. 98 Закону, та інших завдань, визначених Законом про банкрутство.

Якщо в ході ліквідаційної процедури у справі про банкрутство не виявлено рухомого та нерухомого майна, грошових коштів, дебіторської заборгованості, тобто, будь-яких активів, то оплата послуг ліквідатора боржника повинна здійснюватись за рахунок грошових коштів кредиторів по справі (постанови ВГСУ від 27.10.2015 р. у справі № 911/1056/13 [8], від 11.02.2015 р. у справі № 43/137 [9], від 08.11.2016 р. у справі № 915/1961/14 [10], від 25.10.2016 р. у справі № 925/2063/13 [11]). 
Законодавець не ставить вказаний порядок розподілу витрат на оплату послуг ліквідатора в залежність від майнового стану кредитора у справі про банкрутство, його правового статусу, а також від джерел фінансування того чи іншого кредитора.

Згідно зі ст. 13 Конвенції про захист прав людини і основоположних свобод кожен, чиї права та свободи, визнані в цій Конвенції, було порушено, має право на ефективний засіб юридичного захисту в національному органі, навіть якщо таке порушення було вчинене особами, які здійснювали свої офіційні повноваження [12].

Широке тлумачення Європейським судом з прав людини цієї норми покладає на суд обов'язок захистити право особи (по відповідній справі конституційне право ліквідатора на оплату праці) в такий спосіб, щоб порушене, невизнане або оспорюване право отримало ефективний та справедливий спосіб захисту.

Наведене вище дає підстави для висновку, що підхід до інтересу кредитора при вирішенні питання про стягнення оплати послуг ліквідатора має відповідати положенням не лише Закону про банкрутство, але й міжнародним правовим актам, забезпечувати в такий спосіб єдиний підхід до застосування положень цього Закону, втілювати принципи правової визначеності та верховенства права.

Відсутність чіткого нормативного регулювання у профільному Законі питання оплати праці ліквідатора за рахунок коштів кредиторів не може бути підставою для відмови у задоволенні вимог про оплату праці, які також грунтуються на положеннях нормативних актів, котрі мають вищу юридичну силу.

В силу ст. 11 Господарського процесуального кодексу України [13] суд розглядає справи відповідно до Конституції України, законів України, міжнародних договорів, згода на обов'язковість яких надана Верховною Радою України; застосовує інші правові акти, прийняті відповідним органом на підставі, в межах повноважень та у спосіб, що встановлені Конституцією та законами України.

Права і свободи людини та їх гарантії визначають зміст і спрямованість діяльності держави (ст. 3 Конституції України). Права і свободи людини i громадянина, закріплені Конституцією, не є вичерпними. Конституційні права i свободи гарантуються і не можуть бути скасовані (ст. 22 Основного Закону).

На підставі ст. 43 Конституції України кожен має право на належні, безпечні і здорові умови праці, на заробітну плату, не нижчу від визначеної законом. Право на своєчасне одержання винагороди за працю захищається законом.

Таким чином, норми Закону про банкрутство, які визначають право ліквідатора на оплату послуг, конкретизують положення Основного Закону, є правовою підставою для отримання ліквідатором винагороди за виконану роботу.

Законом про банкрутство передбачена певна сукупність дій, яку необхідно вчинити розпоряднику майна, ліквідатору в ході відповідних судових процедур, що застосовуються до боржника.

Отже, у випадку належного виконання обов'язків, арбітражний керуючий повинен мати право на отримання винагороди за рахунок кредиторів. 
Права кредиторів у цьому випадку забезпечуються шляхом надання права відмовитись від задоволення своїх вимог у будь-який час, контрольною функцією суду 3 перевірки дотримання вимог Закону при виконанні арбітражним керуючим покладених на нього обов'язків.

Тому, доцільно закріпити у Законі про банкрутство можливість пропорційного стягнення з кредиторів винагороди арбітражного керуючого.

Виняток лише мають становити справи, порушені за заявою боржника, або ліквідаційна процедура за правилами ст. 95 Закону, оскільки необхідною умовою порушення провадження у справі $є$ достатній обсяг активів боржника для покриття витрат ліквідаційної процедури, в тому числі і з оплати винагороди арбітражного керуючого. Тобто презюмується відшкодування винагороди за рахунок майна боржника, а не кредиторів.

Окремо необхідно зупинитись на врегулюванні питання відшкодування винагороди арбітражного керуючого у випадку продажу заставного майна. Згідно з позицією ВГСУ у справі № 15/9-10 (постанова від 04.02.2015 р. [14]) кошти, отримані ліквідатором від продажу заставного майна боржника, одразу підлягають перерахуванню у повному обсязі заставодержателю. Отже, грошові кошти повинні перераховуватись на користь заставного кредитора не пізніше наступного дня після їх зарахування на ліквідаційний рахунок.

У зв'язку з цим вбачається, що справедливим є обчислення грошової винагороди ліквідатора саме станом на зазначену дату, оскільки після отримання заставним кредитором задоволення вимог за рахунок грошових коштів, отриманих від продажу заставного майна, припиняється фактичне понесення витрат, пов'язаних з його утриманням, збереженням та реалізацією.

Згідно зі ст. 42 Закону про банкрутство майно банкрута, що є предметом забезпечення, не включається до складу ліквідаційної маси і використовується виключно для задоволення вимог кредитора за зобов'язаннями, які воно забезпечує.

Водночас, кошти, що залишилися після задоволення забезпечених вимог та покриття витрат, пов'язаних 3 утриманням, збереженням та продажем предмета забезпечення, підлягають включенню до складу ліквідаційної маси. Тобто, визначаючи пріоритет у задоволенні вимог забезпеченого кредитора за рахунок коштів, отриманих від реалізації предмета застави, законодавець визначив гарантію відшкодування витрат, понесених у зв'язку з реалізацією такого майна.

Отже, право забезпеченого кредитора на першочергове задоволення вимог не має повністю абсолютного характеру, а має реалізовуватись 3 дотриманням прав інших учасників процесу.

Витрати, пов'язані з утриманням, збереженням та продажем предмета забезпечення здійснюються виключно ліквідатором шляхом виконання покладених на нього обов'язків, залучення спеціалістів, тощо.

Нормативне формулювання «витрати пов'язані з» свідчить про необхідність його широкого тлумачення, тобто мають бути враховані усі види витрат, 
які спрямовані на забезпечення утримання, збереження та продаж предмета забезпечення.

Аналогічну правову позицію висловлено Конституційним Судом України у рішенні від 28.04.2010 року у справі № 1-30/2010 [15] за конституційним зверненням громадянина Суботи Артема Анатолійовича щодо офіційного тлумачення положень пункту 2 частини першої статті 293 Цивільного процесуального кодексу України (справа про забезпечення апеляційного оскарження ухвал суду), в рамках якої надано офіційне тлумачення положень стосовно можливості апеляційного оскарження ухвал щодо забезпечення позову.

Положення ст. 45 Закону про банкрутство визначає перелік витрат, котрі пов'язані з провадженням у справі про банкрутство в господарському суді та роботою ліквідаційної комісії, у тому числі: виплата основної грошової винагороди арбітражному керуючому.

Отже, до складу витрат, котрі мають бути відшкодовані за рахунок грошових коштів, отриманих від реалізації заставного майна, також належить оплата праці ліквідатора.

Право вимоги основної грошової винагороди виникає в арбітражного керуючого в останній день кожного календарного місяця виконання ним повноважень керуючого санацією, ліквідатора (ч. 3 ст. 115 Закону про банкрутство).

Таким чином, право вимоги 3 оплати грошової винагороди ліквідатора виникає щомісячно, тобто таке право об'єктивно існує станом на час надходження коштів від продажу заставного майна.

Водночас, першочергове право заставного кредитора гарантовано ст. 42 Закону про банкрутство і виникає $з$ моменту зарахування грошових коштів на ліквідаційний рахунок боржника.

Виходячи 3 цього, право на задоволення вимог за рахунок грошових коштів, отриманих від реалізації заставного майна існує як у заставного кредитора, так і особи, яка понесла витрати, пов'язані з утриманням, збереженням та продажем предмета забезпечення, включаючи оплату праці арбітражного керуючого.

Як зазначалось вище, нормативно визначено три джерела оплати послуг ліквідатора: наявні у боржника кошти, одержані у результаті господарської діяльності боржника; кошти, одержані від продажу майна (майнових прав) боржника; кошти фонду авансування грошової винагороди та відшкодування витрат арбітражного керуючого, сформованого кредиторами. Тому у випадку реалізації заставного майна єдиним джерелом оплати послуг арбітражного керуючого є кошти, одержані від продажу майна (майнових прав) боржника, які перебувало у заставі.

Факт перерахування грошових коштів на користь заставного кредитора не звільняє останнього від обов'язку відшкодувати понесені у ліквідаційній процедурі витрати з оплати послуг арбітражного керуючого.

При цьому неспіврозмірним $є$ задоволення вимог ліквідатора 3 оплати винагороди виключно за рахунок коштів, перерахованих заставному кредитору, оскільки ліквідатор вчиняє дії в інтересах усіх кредиторів одночасно. Тому слід 
дотримуватись принципу пропорційного покладення на кредиторів обов'язку 3 оплати праці арбітражного керуючого.

Відтак, заставний кредитор за рахунок отриманих коштів від реалізації майна, яке було предметом забезпечення, зобов'язаний сплатити винагороду арбітражного керуючого, визначену на момент зарахування грошових коштів на ліквідаційний рахунок, у частці, що відповідає розміру його вимог від загальної кількості усіх визнаних судом вимог кредиторів.

Підсумовуючи вищевикладене, пропонується закріпити обов'язок заставного кредитора відшкодовувати ліквідатору розмір винагороди за рахунок коштів, отриманих від продажу заставного майна, пропориійно частки кредиторських вимог від сукупності грошових вимог, визнаних судом.

На основі проведеного дослідження можна також зробити висновок, щз при обчисленні розміру винагороди арбітражного керуючого слід брати до уваги розмір фактично виплаченої заробітної плати, а не нарахованої до виплати. Мінімальний розмір винагороди ліквідатора, керуючого санацією не може бути нижчим за дві мінімальні заробітні плати. Ліквідатор має право на оплату винагороди у випадку фактичного здійснення повноважень у справі про банкрутство.

Для иьвого необхідно внести зміни до ст. 115 Закону про банкрутство, включивши положення про обов'язок кредиторів оплачувати грошову винагороду арбітражного керуючого за відсутності активів підприємства-банкрута.

Висловлені пропозиції $\epsilon$ лише орієнтиром для подальших наукових досліджень, які мають зосередитись на визначенні справедливого балансу між інтересами боржника, кредиторів та арбітражного керуючого у питаннях обчислення та виплати грошової винагороди останньому.

1. Про відновлення платоспроможності боржника або визнання його банкрутом: Закон України від 14 травня 1992 р. № 2343-XII. Відомості Верховної Ради України. 1992. № 31. Ст. 440. (Із змінами).

2. Міньковський С. В. Правове регулювання оплати грошової винагороди та відшкодування витрат розпоряднику майна у справі про банкрутство. Офіційний веб-портал Судової влади України. URL: https://hr.arbitr.gov.ua/ sud5023/publication/71291/.

3. Пригуза П. Д. Проблеми оплати послуг арбітражного керуючого в Україні. URL: http://yurincom.com/ua/legal_practice/analitychna_yurysprudentsiia/_problemy_oplaty_poslug_ arbitrazhnogo_keruiuchogo_v_ukraini-publication/.

4. Погребняк Г. О. Щодо виплати грошової винагороди та відшкодування витрат арбітражному керуючому у справах про банкрутство. SWorld. 19-26 April 2016. URL: https://www.sworld.com.ua/konferm3/254.pdf.

5. Про затвердження Порядку обчислення середньої заробітної плати: Постанова Кабінету Міністрів України від 8 лютого 1995 р. № 100. Офіиійний веб-портал Верховної Ради України. URL: http://zakon5.rada.gov.ua/laws/show/ 100-95-\%D0\%BF.

6. Інформаційний лист Вищого господарського суду України «Про Закон України «Про відновлення платоспроможності боржника або визнання його банкрутом» (у редакції Закону України від 22.12.2011 № 4212-VI). Офіиійний веб-портал Верховної Ради України. URL: http://zakon3.rada.gov.ua/laws/show/ v_606600-13. 
7. Конституція України: Прийнята на п’ятій сесії Верховної Ради України 28 червня 1996 р. № 254к/96-ВР. Відомості Верховної Ради Украӥни. 1996. № 30. Ст. 141. (Із змінами).

8. Постанова Вищого господарського суду України від 27 жовтня 2015 р. у справі № 911/1056/13. Сдиний державний реєстр судових рішень. URL: http://www.reyestr.court.gov. ua/Review/52953265.

9. Постанова Вищого господарського суду України від 11 лютого 2015 р. у справі №43/137. Єдиний державний реєстр судових рішень. URL: http://www.reyestr.court. gov.ua/Review/42704700.

10. Постанова Вищого господарського суду України від 8 листопада 2016 р. у справі №915/1961/14. Єдиний державний реєстр судових рімень. URL: http://www.reyestr.court. gov.ua/ Review/62593215.

11. Постанова Вищого господарського суду України від 25 жовтня 2016 р. у справі № 925/2063/13. Єәиний державний реєстр судових рімень. URL: http://www.reyestr.court. gov.ua/Review/62496996.

12. Конвенція про захист прав людини і основоположних свобод від 4 листопада 1950 p. Офіиійний веб-портал Верховної Ради Украӥни. URL: http://zakon3.rada.gov.ua/laws/ show/995_004.

13. Господарський процесуальний кодекс України: Закон України від 3 жовтня 2017 р. № 2147-19. Відомості Верховної Ради України. 2017. № 48. Ст. 436.

14. Постанова Вищого господарського суду України у справі від 4 лютого 2015 р. № 15/9-10. Єоиний державний реєстр судових рішень. URL: http://www.reyestr.court. gov.ua/Review/42627029.

15. Рішення Конституційного Суду України від 28 квітня 2010 р. у справі № 1-30/2010. Офіиійний веб-портал Верховної Ради Украӥни. URL: http://zakon3.rada.gov.ua/laws/show/ v012p710-10. 